\title{
ANONYMOUS WITNESSES
}

\section{Ruth Costigan, Lecturer in Law, University of Wales Swansea and Professor Philip A Thomas, Cardiff Law School}

Seasoned observers of Northern Ireland's criminal justice system are familiar with a pattern of restrictive laws migrating to the legal system of England and Wales after a process of "normalisation" initiated in Northern Ireland. So it is with the granting of anonymity to witnesses in criminal trials. The second inquiry into Bloody Sunday has brought the reality of witness anonymity to public notice. ${ }^{2}$ Yet what has remained hidden is the increasing use of anonymous witnesses in criminal trials, a practice which has its roots in an exceptional trial in Northern Ireland but which has progressed swiftly through the process of normalisation so that it now affects routine prosecutions throughout the United Kingdom. This article traces the development and the expanding usage of anonymous witnesses and questions both the validity and appropriateness of the increasing acceptance of witness anonymity within the criminal justice system.

Witness intimidation is a major issue for agencies concerned with law enforcement and criminal justice. ${ }^{3}$ The public interest in the prosecution of offences and the interests of those affected by intimidation require a response to actual and feared ${ }^{4}$ retribution. Indeed, the Human Rights Act 1998 will enable vulnerable witnesses to raise Convention rights, notably those

* Grateful thanks to Helen Power (University of Glamorgan Law School), Penny Smith (Cardiff Law School) and David Campbell (Cardiff Law School) for their valuable comments on the draft.

1 For discussion of the process of normalising the abnormal, see J Sim and P A Thomas, "The Prevention of Terrorism Act: Normalising the Politics of Repression" (1983) JLS 71.

2 See B Hadfield, " $R$ v Lord Saville of Newdigate, ex $p$ anonymous soldiers: What is the Purpose of a Tribunal of Inquiry?" [1999] PL 663.

3 See for example, Speaking up for Justice: Report of the Interdepartmental Working Group on the Treatment of Vulnerable or Intimidated Witnesses in the Criminal Justice System (1998, Home Office); The Statement of National Standards of Witness Care in the Criminal Justice System (1996, Home Office); Law Commission Report No. 245, Hearsay and Related Topics (1997); The Stephen Lawrence Inquiry. Report of an Inquiry by Sir William Macpherson, Cm 4262 - I, (1999); Masefield's Progress: How Heavy is the Administrative Burden on the Police Now? HM Inspectorate of Constabulary Report (1997). A specific offence of witness intimidation exists in s 51, Criminal Justice and Public Order Act 1994 (as amended by Youth Justice and Criminal Evidence Act 1999, sch 4). The Youth Justice and Criminal Evidence Act 1999 contains a wide range of witness protection measures at the trial court's disposal. In 1996 Irene Adams' unsuccessful Witness Protection Bill proposed a statutory power to grant long-term anonymity to witnesses of organised violence or drug-related offences.

4 Unsurprisingly, witnesses' fear is disproportionate to the incidence of reprisals: W Maynard, Witness Intimidation: Strategies for Prevention, Police Research Group, Crime Detection and Prevention Series Paper No. 55 (1994; London: Home Office). 
provided in Articles 2 (the right to protection of life by law) and 8 (the right to respect for private and family life), in support of a claim for protection. ${ }^{5}$ It is vital, nonetheless, to remain vigilant of the accused's right to a fair trial, which we contend is threatened by the current law and practice relating to witness anonymity. ${ }^{6}$ The first section of this article introduces the consequences of anonymity for fundamental principles of criminal justice. Section two considers the enhanced status conferred on the witness by anonymity and draws on popular culture for insights into this process. We then examine in detail, in sections three and four, the evolution of the anonymous witness, from judicial hearings involving agents of the state to commonplace trials with unidentified civilian witnesses. Finally, we assess the compatibility of domestic law with Article 6 of the European Convention for the Protection of Human Rights and Fundamental Freedoms (hereafter "ECHR"), which provides a number of rights to ensure a fair trial.

\section{JUSTICE BLINDFOLDED}

A fundamental feature of British justice is that its courts, procedures and participants are open to public scrutiny. Practitioners even in the most challenging of cases remain committed to it. ${ }^{7}$ This tradition has been described as Britain's "most enduring contribution to the law of other nations." It is not only justice itself which is served by openness: the maintenance of public confidence is dependent upon the process being subject to scrutiny by the individual and the media. Secret trials are antidemocratic and abusive. Only in exceptional circumstances and if the overall interests of justice demand it may this principle be set aside:

"[T] he broad principle is that the courts of this country must . . administer justice in public. [But] as the paramount object must always be to do justice, the general rule as to publicity. . . must accordingly yield. But the burden lies on those seeking to displace its application in the particular case to make out that the ordinary rule must as of necessity be superseded by this paramount consideration. . . The. . . [judge] must treat [the question] as one of principle, and as turning, not on convenience, but on necessity... . He who maintains that by no other means than by such a hearing can justice be done may apply for an unusual procedure. But he must make out his case strictly and bring it up to the standard which the underlying principle requires."

5 See, for example, Ludi v Switzerland (1993) 15 EHRR 173; Doorson v Netherlands (1996) 22 EHRR 330.

6 See also, G Marcus, "Secret Witnesses" [1990] PL 207.

7 See for example, J Temkin, "Prosecuting and Defending Rape: Perspectives from Inside and Outside the Bar" (2000) JLS 219. Professor Temkin interviewed thirteen barristers with extensive experience of rape trials and found that they viewed the use of screens as contrary to open justice.

8 G Robertson, Freedom, the Individual and the Law (7th ed, 1993), p 345.

9 Scott v Scott [1913] AC 417, Viscount Haldane LC at 437-38. 
In Attorney General v Leveller Magazine, ${ }^{10}$ Lord Diplock affirmed that, "The English system of administering justice does require that . . . in criminal cases. . . all evidence communicated to the court is communicated publicly." 11 This particular aspect of open justice is vital, for as Wigmore observed, public testimony produces:

"In the witness' mind a disinclination to falsify; first, by stimulating the instinctive responsibility to public opinion, symbolised in the audience, and ready to scorn a demonstrated liar; and next, by inducing the fear of exposure of subsequent falsities through disclosure by informed persons who may chance to be present or to hear of the testimony from others present." 12

The use of anonymous witnesses in criminal trials endangers the fair administration of justice: at a general level, in the challenge to open justice, and, more specifically, in relation to the legal rights of the accused. Of prime importance is the defence's Hohfeldian ${ }^{13}$ claim-right to examine the credibility and reliability of prosecution witnesses, termed the "right of confrontation". This right is enshrined in United Kingdom jurisprudence, ${ }^{14}$ Article 6 of the ECHR, ${ }^{15}$ Article 14 of the International Covenant on Civil and Political Rights ${ }^{16}$ and in the Sixth Amendment to the United States Constitution. ${ }^{17}$ The right of confrontation is based on the need to "constitutionalise a barrier against flagrant abuses, trials by anonymous accusers, and absentee witnesses." 18 Three main aims are served by the right: the facilitation of cross-examination (the "greatest legal engine ever invented for the discovery of truth"); ${ }^{19}$ the presence in the courtroom of witnesses, enabling the tribunal of fact to assess credibility through observation of demeanour; and the provision of testimony on oath, guarding against falsehood. Where the right of confrontation is undermined, the presumption

10 [1979] AC 440.

11 Ibid, at 449-50.

12 J H Wigmore, Evidence (Chadbourn revision, 1976) vol 6, 435-36.

13 W N Hohfeld, "Some Fundamental Concepts as Applied in Judicial Reasoning" (1913) 23 Yale LJ 16; Fundamental Legal Conceptions (Yale University Press, 1919). In Hohfeld's analysis, a claim-right is legally enforceable and imposes a correlative duty.

14 See, for example, $R$ v Radak and others (1998) The Times, 7 October (CA).

15 Article 6(1): "In the determination of his civil rights and obligations or of any criminal charge against him, everyone is entitled to a fair and public hearing within a reasonable time by an independent and impartial tribunal established by law... (3) Everyone charged with a criminal offence has the following minimum rights. . . (d) to examine or have examined witnesses against him and to obtain the attendance and examination of witnesses on his behalf under the same conditions as witnesses against him. ..".

16 The relevant provisions essentially reflect the language of Article 6 of the Convention, supra.

17 "In all criminal prosecutions, the accused shall enjoy the right to a speedy and public trial, by an impartial jury. . . and to be informed of the nature and cause of the accusation; [and] to be confronted with the witnesses against him. ..".

18 California v Green 399 US 149 [1970] at 179.

$19 \mathrm{Ibid}$, at 158, citing 5 Wigmore $\S 1367$. 
of innocence and the principle of full proof (reflected in the standard of proof beyond reasonable doubt) are also threatened.

In the South African case of $S \mathrm{v}$ Leepile (1985), ${ }^{20}$ Ackermann J identified the principal restrictions on the defence where anonymous witnesses are employed:

“(a) No investigation could be conducted by the accused's legal representatives into the witness' background to ascertain whether he has a general reputation for untruthfulness, whether he has made previous inconsistent statements nor to investigate other matters which might be relevant to his credibility in general. (b) It would make it more difficult to make enquiries to establish that the witness was not at places on the occasions mentioned by him. (c) It would further heighten the witness' sense of impregnability and increase the temptation to falsify or exaggerate." 21

This statement encapsulates the importance of the accused's right to crossexamine prosecution witnesses and thereby challenge their credibility. The Supreme Court of the United States has also recognised the importance of the right to explore a witness' background:

"When the credibility of a witness is in issue, the very starting point in 'exposing falsehood and bringing out the truth' through cross-examination must necessarily be to ask the witness who he is and where he lives. The witness' name and address open countless avenues of in-court examination and out-of-court investigation. To forbid this most rudimentary inquiry at the threshold is effectively to emasculate the right of cross-examination itself. . . . Prejudice ensues from a denial of the opportunity to place the witness in his proper setting and put the weight of his testimony and his credibility to a test, without which the jury cannot fairly appraise them." 22

Where anonymous witnesses are used, the defence is disadvantaged not only by severe limitations on strategy; it is also prejudiced by the symbolism of unidentified, physically screened witnesses. In addition to the elevation of the witness' status (discussed below) there is the risk that the jury might infer that the defendant is a dangerous person, thus undermining the presumption of innocence. The use of screens is appropriate in some cases, particularly those involving charges of child abuse, but such practice causes particular difficulty where the protected witness is also anonymous. The leading case in England and Wales on the use of screens is $R \vee X Y Z(1990),{ }^{23}$ in which the Court of Appeal sanctioned the trial judge's decision to protect child witnesses from the gaze of the defendants who were charged with sexually

20 v Leepile and Others (5) (1986) 4 SA 187

21 Ibid, at 189.

22 Smith v State of Illinois 390 US 129 [1968], at 131-32, citing Pointer v Texas 380 US 404 [1965] and Alford v United States 282 US 687 [1931] respectively.

23 (1990) 91 Cr App R 36. 
abusing them. ${ }^{24}$ In response to the claim that the screens risked prejudicing the jury, the appellate court commented: "We do not think, even without the warning which the learned judge did give to the jury, that any sensible jury could have been prejudiced against the defendant by the existence of this barrier between the witnesses and the dock." 25 In $R$ v Schaub and Cooper (1994), ${ }^{26}$ the Court of Appeal considered the propriety of screening an adult witness (a rape victim) from the accused. In this situation, the Court was more cautious:

"There can be little doubt in our judgement that the use of screens is prejudicial to an accused person, even where the jury are properly warned not to make any assumptions adverse to the accused person because of the presence or use of screens. The very fact that they are being employed at all suggests to a jury that there is a need for the witness to be protected in some way from any contact, even if it is only visual, with the defendant. Accordingly, the defendant is to some extent at a disadvantage. In our judgement, it should only be in the most exceptional cases that apparatus of this kind should be used when an adult is giving evidence." 27

Following the high-profile rape trials of Ralston Edwards and Milton Brown, ${ }^{28}$ Parliament recognised the trauma experienced by adult witnesses in sexual abuse cases: the Youth Justice and Criminal Evidence Act 1999 provides for the screening of such witnesses and of other witnesses who might be afraid or distressed by the prospect of testifying. ${ }^{29}$ However, the endowment of anonymity increases the prospect of prejudice aroused by the presence of screens, and as the appellate court has recognised, admonitions to the jury are of limited efficacy.

\section{ANONYMOUS “SUPERWITNESSES"}

The unidentified or screened witness is, and is perceived as, different from the named, visible witness. The special status enhances the deviation from normal practice in that signifiers upon which evidential evaluations are based are excluded. Michael Mansfield QC who has appeared as defence counsel in cases involving anonymous witnesses observed that, "The hidden witness does nothing to advance the cause of justice. Rather it encourages the development of value judgements about the witnesses' credibility which are based on the granting of anonymity rather than on the evidence itself." ${ }^{30}$ This

24 This was an exercise of the trial judge's common law discretion in furtherance of his duty to ensure a fair trial, consequently no authority was needed to justify his decision. The use of screens in cases involving children has in many cases been obviated by the statutory power to receive a child's evidence given remotely via a live video-link (Criminal Justice Act 1988, s 32 as amended by Criminal Justice Act 1991, s 55).

25 (1990) 91 Cr App R 36, at 40.

26 [1994] Crim LR 531.

$27 R$ v Schaub and Cooper, CA, 29 November 1993; transcript.

28 (1998) The Times, 7 May.

29 Ss 17, 23; the Act also prohibits cross-examination in person by those charged with sexual offences (s 34).

30 Interview with Philip Thomas, 1998. 
observation is supported by Jane Winter, director of British Irish Rights Watch: "In the course of sending independent observers to trials and inquests in Northern Ireland over the past seven years it has been our experience that screening and anonymity, usually linked to public interest immunity certificates, have been increasingly used to hide the identity of key police and army witnesses. In our view, such devices do nothing to assist in establishing the facts of the case or delivering a fair trial." 31

We constantly make judgements, silent or otherwise, about people. Police officers, for instance, have to make instantaneous decisions concerning appropriate responses in fast changing public situations. Skolnick observed that officers develop profiles of "symbolic assailants" who might, for example, wear leather jackets, motor bike boots and "strut" around. Having identified the potential aggressor the interactive behaviour is modified to respond accordingly. ${ }^{32}$ Similarly, MacInnes argues that police officers have a profound dislike of "people loitering in streets, dressing extravagantly, speaking with exotic accents, being strange, weak, eccentric, or simply [appearing to belong to] any rare minority - of their doing, in fact, anything that cannot be safely predicted." 33 The power of the stereotype to influence judgements about criminality was notoriously demonstrated in the work of Cesare Lombroso (1836-1909), who converted stereotypes into "scientific facts." His standard criminal appearance reflected prominent rodent-like incisors, a receding or flat chin with little or no beard, bushy eyebrows which either joined or had a devilish curl at the outer ends. Murderers often had dark rather than blond hair and fraudsters tended towards curly hair. Whilst Lombroso's "science" has been discredited, the power of the stereotype continues:

"How can you possibly say that a person looks like a criminal? Several policemen talk about the ability to 'feel' or 'smell' a criminal, or to have a 'sixth sense' about a person. What they are really talking about is the ability to see a criminal when they come across one. It is basically a question of being able to categorise or stereotype a person ... the most skilful policeman will therefore not only be able to recognise a criminal when he sees one but will often be able to state what type of previous convictions the particular criminal has." 34

31 Private correspondence with the authors, 1998.

32 J H Skolnick, Justice Without Trial: Law Enforcement in Democratic Society (1966).

33 Mr Love and Justice (1962).

34 J Robinson, Catching Criminals: Some Basic Skills (1978). Several studies suggest that facial stereotypes exist for various types of criminals. See for example, G R Thornton, "The Ability to Judge Crimes from Photographs of Criminals" (1939) $J$ of Abnormal and Social Psychology 378-83; R H C Bull and J Green, "The Relationship between Physical Appearance and Criminality" (1980) Medical Science Law 79-83; A G Goldstein, J E Chance \& B Gilbert, "Facial Stereotypes of Good Guys and Bad Guys" 22 Bulletin of Psychonomic Society, 549-52. For a general account of crime and facial appearance see R Bull and N Rumsey, The Social Psychology of Facial Appearance, 1988, chapter 4: "Facial appearance and the criminal justice system" 81-101. 
Judging the individual is an action members of the jury have undertaken on countless social occasions. But doing so in court is a new experience, subject to different rules and a restricted set of indicators. The formal and social rules that operate within the court privilege the regular actors: the professionals, the court staff and the police. An arcane linguistic code is employed to control the involvement of the witness and the defendant. ${ }^{35}$ Features such as dialect, ${ }^{36}$ appearance, ${ }^{37}$ ethnicity, ${ }^{38}$ gender, status and demeanour affect witness credibility. The United States Supreme Court has explained that jurors must be able to see the witness, so that they may "judge his demeanour upon the stand and the manner in which he gives his testimony whether he is worthy of belief." ${ }^{39}$ In Coy v Iowa (1988), ${ }^{40}$ the Court observed that the right of confrontation is guaranteed the defendant "because it is always more difficult to tell a lie about a person to his face than behind his back." 41 As Jerome Frank commented,

"All of us know that, in everyday life, the way a man behaves when he tells a story - his intonation, his fidgeting or composure, his yawns, the use of his eyes, his air of candour or of evasiveness - may furnish valuable clues to his reliability. Such clues are by no means impeccable guides, but are often immeasurably helpful. So the courts have concluded." 42

Shepherd, a forensic psychologist and psychotherapist, has noted that, "judgements of initial credibility arise from the manner in which the oath is taken, comportment and the representation of reality (material facts) and non-verbal cues exhibited when giving this through the process of examination-in-chief." When evaluating witnesses, jurors use "four key elements: language, intonation, sounds outside language and, finally, body language such as posture, facial expression, eye contact and gaze." 43

The face is widely recognised as the most important area of our bodies in influencing and regulating personal interactions; ${ }^{44}$ it is the principal area on which the viewer concentrates for non-verbal communication. For example, if actors, poker players and politicians were unable to control or manipulate their faces their status, income and credibility would be severely affected. Identifying the lie is difficult but it is a popular belief that the face is a mirror, albeit sometimes cloudy, which reflects the honesty of the individual. However, research suggests that exposure to liars does not produce greater

35 See, for example, P Carlen, "Remedial Routines for the Maintenance of Control in Magistrates' Courts" (1974) BJLS 101.

36 See W M O'Barr, Linguistic Evidence: Language, Power and Strategy in the Courtroom (1982); Hans and Vidmar, Judging the Jury (1986).

37 See, for instance, J Temkin, op cit $\mathrm{n} 7$.

38 See Hans and Vidmar, Judging the Jury (1986).

39 Mattox v US 156 US 237, 242-43 (1895).

40 Coy v Iowa 487 US 1012 (1988).

41 Ibid, at 1016, 1019.

42 J Frank, Courts On Trial (1950), p 21.

43 Taken from an opinion from Dr Shepherd, generously provided by Bindman and Partners, London (1999).

44 See generally, T R Alley (ed), Social and Applied Aspects of Perceiving Faces (1988); J Liggett, The Human Face (1974); F C McGregor, Transformation and Identity (1974). 
detection acuity, even amongst criminal investigators, polygraphers, judges and psychiatrists. ${ }^{45}$ In view of this and of the dangerously seductive power of the stereotype, it might be thought that the witness' visible presence in court could actually be detrimental to the discovery of the truth. However, we contend that as the whole process of trial is a heavily constructed piece of theatre, to draw a curtain over some of the characters and props paradoxically throws the spotlight on them, distorting their significance and affecting the plot. The combination of the story, the storytellers and the audience produces a complicated pattern within which credibility is established. Words themselves are only part of this process of defining accurate and credible testimony. There are so few Pinocchios that the court is obliged to read the face, observe the demeanour and hear the words of the witness.

The absence of name, occupation, address and, if screened, the person, concentrates the jury's attention on the voice, which might be subject to electronic distortion. The elements of mystery and importance are introduced and endorsed by the state. It is the state, through the prosecution, which claims that this person is so important or vulnerable that only limited access can be allowed to the jury, the defendant, counsel and the public. Such endorsed witnesses become "super-witnesses" whose credibility should neither be tested nor doubted. Who is this person, being so important, that he cannot be identified to the very court which is empowered to test the evidence? Disbelieving or doubting such a witness involves casting doubt on the state's evaluation procedures. For jurors this is a double burden to carry.

It is from literature and popular culture that we receive our directions as to what is good and bad, strong and weak, desirable and undesirable. Mass culture informs the jury as to witness credibility. ${ }^{46}$ Insights into the status anonymity confers on a witness are to be gained from an examination of anonymity as a literary device. Absence of the main character in psychological thrillers is a common technique employed to heighten the character's menace, as exemplified by Patricia Cornwell's serial killer, Temple Gault, whose identity is only revealed to the reader at a late stage in the series of novels built around him. The identity of Alexander Dumas' "Man in the Iron Mask" became a public guessing game; it was simply too important and politically divisive to be revealed. "The Invisible Man" of H G Wells was fascinating because of his apparent lack of physical presence. ${ }^{47}$ Superman, the Lone Ranger, Batman, Robin and Spiderman are, in their bizarre clothing and masked presence, infinitely more exciting than their known alter egos. Clark Kent was able to attract Lois Lane's sexual interest only in his Superman persona. In the 1940s Superman films, audiences were

45 D McNeil, The Face (1998); P Ekman, Telling Lies (1986); O G Wellbourn, "Demeanour" (1991) 76 Cornell LR 1104; M Stone, "Instant Lie Detection? Demeanour and Credibility in Criminal Courts" [1991] Crim LR 821.

46 See the influential work of H Innes, The Bias of Communication (1975) and M McLuhan, Understanding Media, The Extensions of Man (1964); The Gutenberg Galaxy: The Making of Typographic Man (1962).

47 R F Fleissner, "H G Wells and Ralph Ellison: Need the effect of one invisible man on another be itself invisible?" (1992) 33 Extrapolation 346-50; A B Simpson, "The 'Tangible Antagonist': H G Wells and the Discourse of Otherness" (1990) 31 Extrapolation 134-47. 
encouraged to believe that Superman was playing himself by the exclusion of Kirk Alyn's name from the credits. ${ }^{48}$ Clayton Moore, who played the Lone Ranger, was contracted to remain publicly anonymous. Thus the role, not the actor, became the icon. Clint Eastwood's nameless, emotionless cowboy who featured in westerns such as "High Plains Drifter," offered no history and no future; he appeared, dispensed bloody justice and left. On stage, in "The Phantom of the Opera," Christine Daae seeks to snatch the mask from Erik's face; she cries that she "wants to know the face of the voice."

The sociologist, George Simmel, noted that every sense contributes to the messages we receive and thus to the judgements we make of others. ${ }^{49} \mathrm{He}$ believed that "the eye is destined for a completely unique sociological achievement: the connection and interaction of individuals. . perhaps the most direct and purest interaction that exists." 50 Direct eye contact conveys considerable information, offering the observer a version of reality which might or might not corroborate the oral message. In the case of the anonymous witness, the defendant, jury, public and the media are deprived of this source of information. Furthermore, as Simmel observed, secrets adorn and enhance personality: the mask bestows instant mystique. So, paradoxically, the anonymous witness, the one about whom the jury knows the least, has the highest status.

\section{ANONYMOUS STATE AGENTS}

"The Tribunal has as its fundamental objective the finding of the truth about Bloody Sunday. It regards itself as under a duty to carry out its public investigative function in a way that demonstrates to all concerned that it is engaged in a thorough, open and complete search for the truth about Bloody Sunday." "51 "[T]hese are the very soldiers whose conduct lies at the centre of this Inquiry. To allow this group to remain entirely anonymous would be a step that we would find difficult to reconcile with our public duty to determine what happened on Bloody Sunday." 52

As the above statement by the Saville Tribunal (appointed in 1998 to conduct a second inquiry into Bloody Sunday) indicates, the use of anonymous witnesses not only detracts from the appearance of openness but increases the prospect that justice will be obstructed. Despite these dangers, there has in recent years been a quantum leap in the granting of anonymity to state agents, be they police officers or members of the intelligence services, the SAS or the army (soldiers, for example, have routinely testified

48 Alyn recalled, "Playing Superman ruined my acting career. I couldn't get another job in Hollywood." Obituary, The Guardian, 24 March 1999.

49 See D Frisby and M Featherstone, Simmel on Culture (1997) specifically, "Sociology of the Senses" at p 109.

50 Ibid, at 111.

51 Further Rulings by Lord Saville, Mr William Hoyt, Sir Edward Somers, 5 May 1999, para11: http://www.bloody-sunday-inquiry.org.uk.

52 Further Rulings and Observations by Lord Saville, Mr William Hoyt, Sir Edward Somers, 17 December 1998, para 46: http://www.bloody-sunday-inquiry.org.uk. 
anonymously at inquests in Northern Ireland). ${ }^{53}$ The practice of granting anonymity to state agents in judicial hearings has led, through a process of normalisation, to an insidious increase in the use of anonymous civilian witnesses $^{54}$ in criminal trials. Before examining this development, it will be instructive to consider the cost to the fair administration of justice of endowing state agents with anonymity.

One of the most prominent illustrations of this form of secret justice was the inquest into the 1988 killing by British security forces of three unarmed members of the IRA in Gibraltar. ${ }^{55}$ There was widespread concern over the deaths amid suggestions that Sean Savage, Mairead Farrell and Daniel McCann had been summarily executed. ${ }^{56}$ The Home Secretary, Sir Geoffrey Howe attempted to prevent transmission of a television documentary, "Death on the Rock", which challenged the Government's account of the incident. ${ }^{57}$ At the inquest in Gibraltar, eighteen witnesses from the SAS, M15, Special Branch and the local police testified anonymously and from behind a screen. Furthermore, counsel for the United Kingdom government, John Laws, invoked public interest immunity certificates to prevent questioning of witnesses which threatened "national security".

The coroner lacked the power to compel the SAS soldiers to testify and it was doubtful whether they would attend the inquest. Their testimony was eventually secured on assurances of anonymity and screening. The coroner, Felix Pizzarello, commented: "The reality seems to be that unless the witnesses are screened I may not have a meaningful inquest, and, of course, if they are screened it would be a flawed inquest in any case." 58 Journalists' accounts of the inquest reflected the procedural constraints:

"Soldier A was clearly working-class and from the South of England - perhaps London. This much could be deduced from his accent. He was the one who fired the first shot. . Down the street were soldiers $\mathrm{C}$ and $\mathrm{D}$. They were also working-class but from the north: soldier $\mathrm{C}$ was probably from Lancashire. . .

53 For instance, $R$ v Newcastle upon Tyne Coroner, ex p. A (1997, The Times, 19 December) involved a successful challenge to a coroner's refusal to allow a police officer to testify behind a screen at the inquest into the officer's fatal shooting of a burglar. The Divisional Court concerned itself solely with the issue of screens, neglecting to consider the consequences of the anonymity granted to officer "A". For illustrations of soldiers testifying anonymously, see The Guardian: 27 April 1992, 3 February 1993, 10 December 1993, 22 October 1997; The Independent, 7 October 1992.

54 See S Enright, “The Anonymous Witness" (1996) NLJ 1032.

55 The inquest jury returned a majority verdict of lawful killing but, in an unprecedented decision by the European Court of Human Rights, the UK was subsequently found in violation of Article 2 of the ECHR: McCann and others $\mathrm{v}$ UK (1995) 21 EHRR 97.

56 Enoch Powell MP is reported as saying that the security forces might have committed "deliberate, cold-blooded, premeditated murder." The Independent, 1 April 1988.

57 This programme and the surrounding events produced an inquiry which reported as The Windlesham/Rampton Report on Death on the Rock (1989).

$58 \mathrm{~J}$ Tweedie, The Gibraltar Inquest Report (1988) Inquest 5. See also, J Tweedie and T Ward "The Gibraltar Shootings and the Politics of Inquests" 16 (1989) JLS 464. 
Officers $\mathrm{E}$ and $\mathrm{F}$ spoke as though they had attended public school. . . the final witnesses were policeman $\mathrm{P}$, policeman $\mathrm{Q}$ and policeman R." 59

Pizzarello referred to the importance of being able to assess the credibility of the witnesses by their physical demeanour, which in this hearing proved impossible. The soldiers claimed that the three deceased had made suspicious movements on being confronted, as if reaching for a remote detonator. These movements led directly to the shootings which were ostensibly to prevent the detonation of a suspected, but non-existent, car bomb. The screens prevented a comparison of the soldiers' demonstrations with those of eyewitnesses. The soldiers who shot Savage claimed he was facing them and explained the bullet wounds in his back on the basis that he had "corkscrewed" to the ground. Because of the screens their demonstration of the fall was not visible to the public and the press. Whilst these features impacted on the watching world rather than on the jury, there were other illustrations of anonymity which affected the jurors. Photographs of people around the bodies, taken after the shooting, had been doctored; faces were obscured which resulted in civilian witnesses being unable to verify their own observations. ${ }^{60}$

The authors interviewed a former SAS soldier with extensive experience in Northern Ireland. ${ }^{61}$ Having served with soldiers involved in the Gibraltar killings, he observed of that incident: "The soldiers felt pilloried after conducting an excellent operation. They were not happy about giving evidence even after an M15 briefing because of the controversy. They were concerned about being charged with murder. The anonymity was claimed for them although I suspect they would have claimed it anyway." He had direct experience of this when he and four other soldiers, all of whom were involved in a surveillance operation in Northern Ireland, testified anonymously from behind a screen at a criminal trial. The decision to seek anonymity was taken by the army without consultation with the men: "It wouldn't have worried me to give evidence in open court. I am big enough and ugly enough to look after myself. I wasn't afraid. We all felt stupid standing behind a screen. We were professional, elite soldiers and we don't scare easily."

Some of the deficiencies of the "Gibraltar 3" inquest will be apparent in the second inquiry into Bloody Sunday. The Saville Tribunal twice decided ${ }^{62}$ to refuse anonymity to all military witnesses, including those soldiers who had admitted at the Widgery Inquiry ${ }^{63}$ to firing live rounds during the civil rights march of 30 January 1972. Each of these decisions was successfully

59 I Jack "Gibraltar" 25 Granta 1988, 43/44.

60 Ibid.

61 The ex-soldier who had served as a regular soldier for fifteen years insisted on anonymity before undertaking the interview in 1998.

62 See http://www.bloody-sunday-inquiry.org.uk, rulings of 17 December 1998 and 5 May 1999.

63 Report of the Tribunal appointed to Enquire into the Events of Sunday $30^{\text {th }}$ January 1972, which led to the Loss of Life in Connection with the Procession in Londonderry on that Day HC 220, 1971-72, HMSO, London, 1972. 
challenged by way of judicial review. ${ }^{64}$ As a result, the Tribunal announced in July 1999 that it would not appeal further against the orders of certiorari. Accordingly, all soldiers present at Bloody Sunday will give evidence anonymously at the full public hearing which commenced in March 2000. ${ }^{65}$ They will have the further protection of an assurance by the Attorney General that their evidence will not be used against them in any subsequent criminal proceedings. ${ }^{66}$ There is much that could be said about the courts' rejection of the Tribunal's reasons for denying the soldiers anonymity, but of particular relevance here is the courts' approach to the issue of open justice.

The main aim of the second inquiry into Bloody Sunday is, in the Prime Minister's words, that "the truth be established and told." 67 The Widgery Inquiry was discredited, not only because it arguably failed to find the truth but also because its proceedings lacked transparency. As the lawyers for the family of James Wray, who was killed on Bloody Sunday, observed:

"One of the most objectionable features of Widgery was that soldiers gave their evidence under the cloak of anonymity, told lies and were never prosecuted or called to account. If. . . [the Saville] Inquiry adopts the same practice on anonymity, it will attract the same cynicism and disrespect. A process that starts by covering up the names of key witnesses will be seen as yet again covering up the truth. By contrast, an Inquiry which starts by making it clear that it proposes to conceal nothing of relevance and that it expects witnesses to come forward, identify themselves and be subjected to fair and public scrutiny, will deserve and will receive the confidence and participation of the public." 68

The Saville Tribunal initially ruled that the soldiers seeking anonymity bore the obligation of justifying their application, ${ }^{69}$ noting that, "it is not open justice that needs to be justified, but rather any departure from open

${ }^{64} R \mathrm{v}$ Lord Saville of Newdigate and others, ex $p B, O, U \& V$, unreported, 16 March 1999 (DC) and (1999) The Times, 15 April (CA); $R$ v Lord Saville of Newdigate and others, ex p. A and others, (1999) The Times, 22 June (DC) and 29 July (CA).

65 In relation to the soldiers not accused of firing live rounds, the Court of Appeal acknowledged in its judgment of 28 July 1999 that it was for the Tribunal to decide whether they should be accorded anonymity, commenting only that on the material currently before it the Court could not state that a decision to refuse anonymity would be unlawful. In view of the criticism it had received in the Court of Appeal, the Tribunal felt that it had no choice but to extend anonymity to all soldiers, which it did in its ruling of 12 October 1999: http://www.bloody-sundayinquiry.org.uk.

66 This assurance does not, however, amount to an immunity against prosecution: Attorney General Press Notice, 25 February 1999: http://www.bloody-sundayinquiry.org.uk.

67 HC Hansard, 29 January 1998.

68 Lord Gifford QC and Barry Macdonald, submission to the Bloody Sunday Tribunal, 12 November 1998: http://www.bloody-sunday-inquiry.org.uk.

69 Rulings and Observations of the Tribunal on the Matters Raised at the Preliminary Hearing on $20^{\text {th }}$ and $21^{\text {st }}$ July 1998, published 24 July 1998: http://www.bloodysunday-inquiry.org.uk. 
justice."70 The Court of Appeal, however, expressly disapproved of this approach when reviewing the Tribunal's subsequent decisions on anonymity. Lord Justice Otton, in the appellate hearing of March 1999, commented that the Tribunal members "might wish to reconsider the fairness of imposing the obligation 'on those who seek anonymity of any kind to justify their claim'. . . Similarly, they may wish to revisit their requirement that there must be 'concrete evidence of specific threat'."'71 This view was endorsed by Lord Woolf MR in the final judicial review hearing:

"The Tribunal then state. . . that in their judgement "it is not open justice that needs to be justified but rather any departure from open justice.' Again, this paragraph does appear to play down the significance which should be attached to the risk to the soldiers. Surely it could be said equally that the need for increasing the risk to the soldiers has to be justified." 72

Indeed, the appellate court concluded that the Tribunal, having accepted that the soldiers had reasonable grounds to fear for their safety if identified, bore the obligation of finding a compelling justification for refusing anonymity. ${ }^{73}$ This inversion of fundamental principle had previously been manifested by the Divisional Court: "by requiring the applicants to justify a departure from public and open justice. . . [the Tribunal] wrongly gave precedence to the consideration of the carrying out of a public investigation." 74

In addition to departing from the traditional approach to open justice, the courts naively posited that "the open search for the truth would only be restricted in a marginal way" 75 by extending anonymity to the soldiers. This gives insufficient weight to the Tribunal's observation that,

"the conduct of these soldiers lies at the very heart of this Inquiry. It is the firing on the streets that was the immediate cause of loss of life. It is that loss of life that we are publicly investigating. To conceal the identity of those soldiers would . . . make particularly significant inroads on the public nature of the Inquiry." 76

Given the obvious importance of an open investigation, it is surprising that the Court of Appeal felt able to conclude so confidently that, "we do not

70 Further Rulings by Lord Saville, Mr William Hoyt, Sir Edward Somers, 5 May 1999: http://www.bloody-sunday-inquiry.org.uk.

$71 R \mathrm{v}$ Lord Saville of Newdigate and others, ex $p B, O, U \& V$, (1999) The Times, 15 April; transcript.

$72 R \mathrm{v}$ Lord Saville of Newdigate and others, ex p A and others, (1999) The Times, 29 July; transcript.

73 Ibid, para 68 of transcript.

$74 R \mathrm{v}$ Lord Saville of Newdigate and others, ex $p$ A and others (1999) The Times, 22 June.

$75 R \mathrm{v}$ Lord Saville of Newdigate and others, ex $p$ A and others, (1999) The Times, 29 July; para 56 of transcript, Lord Woolf MR. See also the judgment of Roch LJ in $R$ v Lord Saville of Newdigate and others, ex $p$ A and others (1999) The Times, 22 June (DC).

76 Op cit $\mathrm{n} 70$, para 28. 
consider that any decision was possible other than to grant the anonymity to the soldiers." 77

When state agents testify anonymously in criminal trials, it is not only open justice which is at stake: so too are the accused's legal rights. The courts have justified this practice on the basis of protecting the witnesses from physical harm and of preserving their future operational usefulness. Yet the necessity of withholding these witnesses' identities often remains unestablished. Perhaps the clearest illustration of this is $R \vee$ Roberts, Davies and Williams (1993), ${ }^{78}$ the trial of Welsh nationalists for the possession and use of explosives and conspiracy to cause explosions. MI5 had employed 38 officers during covert surveillance of political rallies and of a residence in Anglesey. At trial, Pill J rejected the prosecution's application for the proceedings to be held in camera, but did grant anonymity to security service witnesses. The officers testified as Mr A, B, C, D, E and F from behind a screen. However, outside the court these officers were easily identified as they stayed in one hotel, kept to themselves and spoke English in a predominantly Welsh speaking community.

The interests of "national security" have also been employed to justify anonymity. The Court of Appeal in $R$ v Jack (1998), ${ }^{79}$ an appeal against conviction and sentence for conspiracy to cause explosions, denied that national security was used as a trump card to legitimate the anonymity afforded fourteen Security Service witnesses: "The security services do not have any passport to the use of screens, or to any other form of anonymity. Their position has to be considered as individual witnesses on a case by case basis." An analysis of this case indicates that courts might in future seek to avoid the traditional charge of submissiveness in the face of "national security" claims by justifying abnormal administration of criminal justice on the basis of intelligence agents' fear of reprisals. This approach will, despite the Court of Appeal's protestation in Jack, facilitate the granting of anonymity to undercover police and MI5 officers, an undesirable development particularly in view of the extension of MI5's role into the investigation of "serious crime." 80

At the trial of Jack and his co-defendant, Fryers, the crown sought anonymity for Security Service officers who had engaged in covert surveillance of the two men. The application was supported by a public interest immunity certificate which, the Court of Appeal noted, was "couched in very general terms." The trial judge, after balancing the interest of open justice against that of national security (in accordance with the traditional approach), ${ }^{81}$

$77 R \mathrm{v}$ Lord Saville of Newdigate and others, ex p A and others, (1999) The Times, 29 July; para 69 of transcript, Lord Woolf MR.

78 Unreported. See P A Thomas "Secret Police on Trial" 98 (1993) Planet: The Welsh Internationalist, 3-8 for an account of the trial and the surrounding politics.

$79 R$ v Jack (Hugh Thomas), CA, 7 April 1998, unreported; extracts reproduced from transcript.

80 Security Services Act 1989, s 1(4), inserted by the Security Services Act 1996, s 1.

81 This approach is exemplified in the words of Hutton LCJ: "Where the claim of national security is raised in such a way that it may conflict with the principle of open justice, the court must balance the claims and decide whether there should be a restriction of the principle of open justice in order to meet the claims of national 
granted the request and the witnesses, each identified by a letter, gave their testimony screened from the accused, the press and the public gallery. On appeal, counsel for Jack contested the use of the screens (though not the employment of letters to denote each witness), arguing that the trial judge had given too much weight to the fact that MI5 agents were involved and had paid insufficient regard to the defendant's interests and to the prejudice aroused by the nature of the charges (the prosecution alleged that Jack had acted for the IRA). Jack's counsel, Ben Emmerson, also cautioned the Court about the threat to normal trial procedures posed by the increasing claims to anonymity made by Security Service personnel.

Whilst upholding the trial judge's decision to grant anonymity, the Court of Appeal redefined the balancing exercise to be undertaken in national security cases. The Court, preferring not to pursue arguments based on principles of public interest immunity, indicated that a departure from the principle of open justice may be sanctioned only by reference to the administration of justice and not in furtherance of other public interests. The Court explained that,

"On that basis the balance to be struck is between two aspects of the administration of justice and it is not permissible to balance national security per se against the administration of justice. Statute apart, considerations of national security can justify a departure from the principle of open justice only so far as they have an effect upon the administration of justice itself, e.g. by deterring the crown from continuing a prosecution, or, say, by deterring an individual member of the Security Services from giving evidence out of fear for his own safety." ${ }^{2}$

Although superficially attractive, this decision discourages an in-depth judicial examination of what is required in the interests of national security; the focus on a witness' fear and on the crown's reluctance to call a witness denied anonymity will, it is contended, lead to an increase in the use of anonymous law enforcement witnesses. Further, the Court's ostensible insistence on undercover agents being treated as ordinary individuals when a claim for anonymity is made is at variance with recent ECHR jurisprudence. As the European Court of Human Rights observed in Van Mechelen v The Netherlands, ${ }^{83}$

"The balancing of interests of the defence against arguments in favour of maintaining the anonymity of witnesses raises special problems if the witnesses in question are members of the police force of the State. Although their interests - and

security." $R$ v Coroner for Greater Belfast, Court of Appeal in Northern Ireland, 22 April 1993, unreported.

82 The Court of Appeal did not, however, preclude the possibility of anonymity being justified on the basis of public interest immunity. As the Court concluded that in Jack the considerations of national security and of the administration of justice "merged into one", it left open the question whether a departure from open justice could be justified on the basis of national security issues which had no impact on the administration of justice.

83 (1998) 25 EHRR 657. 
indeed those of their families - also deserve protection under the Convention, it must be recognised that their position is to some extent different from that of a disinterested witness or victim. They owe a general duty of obedience to the State's executive authorities and usually have links with the prosecution; for these reasons alone their use as anonymous witnesses should be resorted to only in exceptional circumstances. In addition, it is in the nature of things that their duties. . may involve giving evidence in open court." 84

Furthermore, ECHR jurisprudence requires that where undercover agents are afforded anonymity as witnesses, the rights of the defence be respected. ${ }^{85} \mathrm{In}$ the Jack case, the prosecution evidence consisted mainly of surveillance reports, yet the defence was unable to investigate the credibility of the anonymous witnesses and was prevented from ascertaining the location of a surveillance camera and the capacity of tracking devices employed to monitor Jack. The appellate court rejected the submission that these circumstances denied counsel the opportunity to present an effective defence. The limitations imposed on the defence by the use of anonymous witnesses were not fully canvassed in the Court of Appeal, but in relation to the screening of witnesses the Court made the remarkable statement that,

"Where the charge under consideration is a terrorist offence the prejudice to the accused of allowing screens to be used is likely to be somewhat reduced, because the jury may have to have protection themselves, and will easily appreciate why, if the charge is well-founded, protection should be afforded to a witness."

A fundamental objection to the courts' approach to cases involving state agents is that they do not entertain the possibility of the intelligence agencies, rather than the defendant, bearing the burden of any compromise between the prosecution of offences and operational efficacy. The judiciary could adopt the position that due process should not be sacrificed for the convenience of the intelligence services, which would have to accept that the price of a prosecution might be the (temporary) transfer or limitation of specific officers' activities. This might prove a burden to law enforcement agencies but it is arguably preferable to the denial of fairly administered criminal justice. In relation to the justification based on protection from physical harm, consideration should be given, where appropriate, to measures short of anonymity (such as press reporting restrictions and other forms of witness protection), which would be more compatible with the accused's right of confrontation. The granting of anonymity to state agents should be on the basis of necessity, rather than convenience, with the court's decision being made on the provision of evidence as to the level of risk to each individual seeking such protection.

${ }^{84}$ Ibid, para 56

85 Van Mechelen op cit $\mathrm{n}$ 83; Ludi v Switzerland op cit $\mathrm{n}$ 5; Kostovski v The Netherlands (1989) 12 EHRR 434; Doorson v The Netherlands op cit $\mathrm{n} 5$. 


\section{THE NORMALISATION OF ANONYMITY}

"The need to be vigilant arises from the natural tendency for the general principle to be eroded and for exceptions to grow by accretion. . . . This is the reason it is so important not to forget why proceedings are required to be subjected to the full glare of a public hearing. It is necessary because the public nature of proceedings deters inappropriate behaviour on the part of the court. It also maintains the public's confidence in the administration of justice. It enables the public to know that justice is being administered impartially. It can result in evidence becoming available which would not normally become available if the proceedings were conducted behind closed doors or with one or more of the parties' or witnesses' identity concealed." 86

The extraordinary is becoming the ordinary; the evolution of the anonymous witness can be traced from judicial inquiries into killings by state agents to committal proceedings for violent disorder. Yet the increasing use of anonymous witnesses is rooted in an inappropriate extension of the common law. Two of the cases employed by courts as authority for witness anonymity do not in fact bear that interpretation. $R$ v Socialist Worker, ex parte Attorney General $(1974)^{87}$ was a contempt case arising from the publication of the names of two prosecution witnesses in a blackmail trial. The witnesses had testified in open court but their names were concealed. At the contempt hearing, it was argued on behalf of Socialist Worker that the trial judge lacked the power to conceal witnesses' names (thus the publication could not be contemptuous). The Divisional Court, however, referred to the long-established practice of allowing blackmail witnesses to remain unidentified in the interest of encouraging victims to testify, thereby facilitating the prosecution of offenders. ${ }^{88}$ Attorney General $\mathrm{v}$ Leveller Magazine (1979) ${ }^{89}$ was also a contempt case, concerning publication of the name of "Colonel B", a prosecution witness in an official secrets trial. The trial judge ordered, without protest from the defence, that Colonel B's name be written down and shown to the court, the defendants and their counsel. The witness then testified in open court. The House of Lords in the ensuing contempt case declared that the concealment of witnesses' identities was an extension of the court's inherent power to hear cases in camera when required for the due administration of justice.

These two cases were used by the trial judge and by the Court of Appeal in Northern Ireland to justify the extensive use of anonymous witnesses in $R$ v Murphy and Maguire (1989), ${ }^{90}$ the first recorded case in which the

${ }^{86} R \mathrm{v}$ Legal Aid Board, ex $p$ Kaim Todner (a firm) [1998] 3 All ER 541, Lord Woolf MR at 548-49.

87 [1974] 3 WLR 801.

88 See Widgery LCJ, ibid, at 804.

89 [1979] 2 WLR 247.

90 Crown Court of Northern Ireland, April 1989, unreported; Court of Appeal in Northern Ireland [1990] NI 306. 
identities of witnesses were withheld from the defence. ${ }^{91}$ This was the first of several trials arising from the murders of Corporals Wood and Howes in West Belfast in March 1988 during the funeral procession of Kevin Brady (killed at the funeral of the "Gibraltar 3" by Loyalist Michael Stone). A considerable amount of photographic and film material, obtained primarily from journalists reporting Brady's funeral, was adduced by the prosecution in Murphy and Maguire. Twenty-seven media witnesses were called, essentially to confirm the material's authenticity and to state the locations from which the images were filmed. In response to a prosecution request, the trial judge, Hutton LCJ, ruled that these witnesses were not to be identified even to the defence; that they would be screened from the view of the defendants, the public and the press; and that the media was not to disclose the name of any witness whose identity it discovered.

Murphy and Maguire is an important authority in the use of anonymous witnesses. But the basis on which Hutton LCJ made his ruling, the Socialist Worker $^{92}$ and Leveller ${ }^{93}$ cases, is flawed. In the Socialist Worker case, the witnesses' names were concealed only from the press and the public, so the defence's ability to cross-examine the witnesses was not limited by anonymity. Similarly, in the Leveller case the defence knew the identity of Colonel B. Indeed, at trial the magistrates refused the prosecution's application for the identity of a different witness to be concealed from the defence. Lord Diplock, in the contempt hearing, stated that the magistrates would not have had the power to make the order sought by the prosecution. These cases, then, provide authority merely for shielding witnesses from publicity. However, the appeal court in Murphy and Maguire was unconcerned about the lack of precedent for withholding witnesses' identity from the accused, stating that the absence of authority "indicates, in our view, nothing more than that the exceptions to the general rule [of open justice] are inevitably various and will continue to be so, for fresh circumstances will create new exceptions." 94

The Murphy and Maguire case illustrates the adage that hard cases make bad law. It marks the incursion of the anonymous witness into "ordinary" criminal trials, a development which was eased by the exceptional circumstances of the case. It is precisely in such highly emotive and politicised trials that the observation of fundamental principles of criminal justice is most needed, yet is most easily dispensed with. This was truly a crime against the state: the murder of two British corporals, at a Republican funeral, by members of the IRA. Its impact was heightened as images of the beatings and killings of the two soldiers were transmitted around the world. It was perhaps predictable that Lord Chief Justice Hutton would accede to the prosecution's request for the media witnesses to testify anonymously, especially as the crown submitted its intention to call the same witnesses in

91 Although there is authority for the proposition that a defendant can be removed from the courtroom if a witness is likely to be intimidated ( $R$ v Smellie (1919) 14 Cr App R 128, CCA) and the use of screens, particularly in cases of child sexual abuse, is now well-established, there was no precedent at the time of Murphy and Maguire's trial for the concealment of witnesses' identities.

92 Op cit $\mathrm{n} 87$.

93 Op cit $\mathrm{n} 89$.

94 [1990] NI 360; at pp 89-90 of transcript. 
dozens of subsequent, related trials. The trial procedures in Murphy and Maguire were abnormal, even in the context of the criminal justice system of Northern Ireland, and the use of anonymous witnesses was unsupported by precedent. Yet the case has been used in England and Wales to establish precedent for the granting of anonymity in routine trials.

The first British case in which civilian prosecution witnesses testified anonymously was $R$ v Brindle and Brindle (1992), ${ }^{95}$ the trial of two brothers for murder. The crown sought anonymity for three material witnesses on the basis of their fear of providing testimony. The trial judge, Denison J, acceded to the crown's request, commenting that,

"If there is a real danger that a witness will not give. . . [material] evidence because of a genuine fear of the consequences if his identity becomes known, then the witness must be given such protection as the Court is able to provide. I use the word 'genuine fear' as opposed to 'justified fear' because it seems to me that it is the state of mind of the witness which is vital. If he is afraid, and if that fear is genuine, then it is not conclusive that no direct threat has been made to him. It seems to me it is sufficient if he genuinely fears retribution and that fear may stem from what some might call rumour or gossip, but which others would call local knowledge."96

To regard a witness' fear as decisive to a claim for anonymity accords inadequate weight to the right to a fair administration of justice, as the European Court of Human Rights recognised three years prior to the Brindle trial. ${ }^{97}$ Moreover, the Court would not countenance the granting of anonymity on the subjective basis proffered by judge Denison. ${ }^{98}$ His judgment continued to reflect a superficial consideration of the defendant's legal rights:

"I recognise that the interests of the defence require that witnesses be seen by the defendant, and if they are not, then there must be. . . some inhibition on the full and proper presentation of the defence. [But] if the wider interests of justice make it necessary for anonymity. . . then the interests of the defence must be subordinated to those wider interests; in particular, that material evidence which is available should be given at the trial."

In accordance with the judge's ruling, all identifying information relating to three material witnesses was withheld from the defendants, their counsel and from the press and public. In addition, the witnesses were screened from the view of the defendants, the press and the public gallery. Although the order related to three specific witnesses, when the trial commenced it became

95 Central Criminal Court, 31 March 1992, unreported; emphases added; transcript extracts are reproduced by permission of Newgate Reporters Ltd.

96 Judge Denison added an inconsistent qualification: "Of course a wholly irrational fear without any foundation could not be regarded as genuine and would not suffice."

97 See Kostovski v The Netherlands (1989) 12 EHRR 434, para 44.

98 See Doorson v The Netherlands (1996) 22 EHRR 330, para 71 at $358-59$; Van Mechelen (1998) 25 EHRR, para 61. 
apparent that all civilian witnesses were to be afforded anonymity. When the defence objected, the witnesses were questioned in the absence of the jury to ascertain their reasons for seeking protection; two admitted they had no need of anonymity. After this examination of the witnesses, all but two were granted anonymity. Denison J observed that his ruling was preferable to the admission of written witness statements, without testimony, under section 23 of the Criminal Justice Act 1988. However, although the Act provides for this arrangement where a witness is too afraid to testify, it also allows for the adduction of evidence relevant to the witness' credibility in order to compensate for the inability to conduct cross-examination. ${ }^{99}$ Whilst principled objections may be made to the admission of section 23 statements, the judge erred in his view that the anonymity order was less restrictive, given the defence's inability to examine credibility where the witness' identity is unknown. Moreover, the Brindle case appears to be the first United Kingdom case in which material witnesses were granted anonymity, representing an extension of the ruling in Murphy and Maguire (heavily relied on by the crown in Brindle). Following the acquittal of the Brindle brothers, journalist Caroline Godwin (aided by two barristers who were so concerned that they acted on a pro bono basis) unsuccessfully sought judicial review of Denison J's decision. Richard Palmer, writing in The Sunday Times, observed that, "The predicament is becoming increasingly common for court reporters in Britain. Secret justice is being handed out in a growing number of cases, often for the flimsiest of reasons." 100

In the same year as the Brindle case, the crown sought witness anonymity in a committal for trial of six defendants charged with violent disorder. Watford Magistrates' Court ordered that eleven witnesses, some of them alleged victims, were to be afforded anonymity through the ascription of colours as pseudonyms, screening from the defendants and testimony via voice-distortion equipment. The committal proceedings were stayed pending the defendants' application for judicial review of the ruling $(R \mathrm{v}$ Watford Magistrates' Court, ex p Lenman). ${ }^{101}$ In response to the applicants' assertion of a common law right of confrontation, Beldam LJ in the Divisional Court declared:

"It is now well established that there may be occasions upon which the interests of justice require that the identity of witnesses should be withheld. This will only rarely be done and on valid cause being shown. Equally, of course, it would be pointless to withhold the identity of the witnesses or the means by which they could be identified if at the same time the circumstances in which they gave their evidence were such that they could by other means, either because of their appearance, or because of the sound of their voices, easily be identified." 102

99 Criminal Justice Act 1988 sch. 2(1).

100 The Sunday Times, 15 August 1993.

101 [1993] Crim LR 388.

102 R Watford Magistrates' Court, ex p Lenman and Others, QBD, 7 May 1992; transcript. 
Despite Beldam LJ's statement that anonymity will be dependent on "valid cause" and on "substantial grounds being shown", his judgment accepts that an assertion of fear on the part of a witness will suffice. Indeed, his Lordship observed that the Divisional Court would not interfere with an anonymity ruling unless it was Wednesbury unreasonable. ${ }^{103}$ Furthermore, the Court failed to illustrate its assertion that the power to grant witness anonymity was well established. The only case cited in the Court's judgment was that of $R \mathrm{v}$ $X Y Z$ (1990), ${ }^{104}$ an authority for the use of screens which did not involve withholding witnesses' identities.

In common with the other cases involving anonymous witnesses, the Divisional Court in ex $p$ Lenman failed to address the accused's specific rights. The applicants contended that the effect of the magistrate's order would be to deprive them of a line of cross-examination: without being able to see a witness (and thus ascertain or challenge his precise location and his behaviour at the scene of the violent disorder), they would be unable to instruct counsel to ask pertinent questions. Beldam LJ responded that since a witness would have given his location in his police statement, the applicants would not be so hampered. This riposte, however, ignores the wider restriction on challenging the witness' credibility beyond the circumstances of the events in question. The judgment gives no sense of engagement with fundamental principles:

"If the rights of an accused and in particular his ability to prepare for and conduct his defence are. . . prejudiced, justice requires the court to balance the prejudice to him and the interests of justice. . . [I]t is difficult to see that there is any but a theoretical prejudice to the applicants in not knowing the identity of. . . [a] person or his precise physical characteristics. . . but there is clear evidence of fear before the magistrate on the part of the witnesses and an unwillingness on their part to give evidence unless protection was provided for them and their identity was not disclosed."105

The public interest in securing witnesses' testimony may justify anonymity in exceptional cases. However, the state has a duty to observe, even facilitate, a defendant's legal rights; any restriction of these entitlements

103 "It is difficult to think of a decision more dependent on the exercise of discretion than the Magistrate's decision in this case. It is plain that this court will not interfere with such a decision unless it can be shown to be so unreasonable that no magistrate, properly considering the question and properly directing himself, could have reached that conclusion." Whilst this would appear to limit a challenge to the strong sense of Wednesbury unreasonableness, it is not altogether clear whether his Lordship intended to exclude Wednesbury unreasonableness in its broader sense; if the former, then successful challenges are highly unlikely. For explanation, see P Leyland and T Woods, Textbook on Administrative Law ( $3^{\text {rd }}$ ed, 1999; London: Blackstone Press), pp $225-227$.

$10491 \mathrm{Cr}$ App R 36. Screens were used in this case solely for the purpose of protecting child victims of sexual abuse from being exposed to the gaze of the defendants.

$105 R \mathrm{v}$ Watford Magistrates' Court, ex p Lenman and Others, QBD, 7 May 1992; transcript; emphasis added. 
must accord with principle and be accompanied by adequate procedural safeguards.

\section{UK JURISPRUDENCE AND ARTICLE 6 OF THE ECHR}

\section{(a) Current UK jurisprudence}

The leading authority in England and Wales on witness anonymity is the Court of Appeal's judgment in $R$ v Taylor (1995). ${ }^{106}$ The trial judge, Denison $\mathrm{J}$ (who also presided over the Brindle trial), acceded to a prosecution request for witness anonymity. "Miss A" gave material evidence for the prosecution in a trial for murder and perverting the course of justice. Her name and address were withheld from the defence and she was protected from sight of the defendants by a screen (though they could see her via a video camera). Despite an admission by Miss A in cross-examination that she was not as fearful of testifying as had been supposed, the judge refused to reconsider the anonymity order. Denison J explained the reason for the order thus:

"This is one of those cases where a balancing act has to be done. On the one hand you have got the requirement of open justice and the hindrance to cross-examination, although. . . in this case I do not think the hindrance is very great. On the other you have got a witness who is frightened. It seems to me. . . that the solution proposed by the Crown is the best compromise and, therefore, I will allow this girl to remain anonymous." 107

The Court of Appeal in Taylor observed that a defendant's right to see and to know the identity of his accusers should only be denied "in rare and exceptional circumstances." But the court made cursory reference to the cases of Smith v Illinois ${ }^{108}$ and $S$ v Leepile ${ }^{109}$ on the basis that they indicated an absolute right of confrontation, and the further case of $R \mathrm{v}$ Murphy and Maguire ${ }^{110}$ which was curiously interpreted as concerning the use of screens, rather than anonymity. The appellate court in the instant case adopted the decision in ex $p$ Lenman ${ }^{111}$ and endorsed Denison J's anonymity ruling, declaring that it was "close to being a model exercise" of discretion.

Evans LJ, giving the judgment of the Court in Taylor, identified five considerations which may justify an anonymity order: ${ }^{112}$ there are real grounds for fearing the consequences of testifying as a named witness; the evidence is so important that it would be unfair to deprive the prosecution of it; the prosecution has fully investigated the witness' credibility; no undue prejudice would be caused by allowing anonymous testimony; and the court can balance the need for anonymity against unfairness to the defendant.

106 [1995] Crim LR 253.

107 Cited by the Court of Appeal, $R$ v Taylor and Crabb, 22 July 1994, transcript.

108390 US 129 [1968].

109 Op cit $\mathrm{n} 20$

110 Op cit $\mathrm{n} 90$.

111 Op cit $\mathrm{n} 101$.

112 The Court noted that the factors were applicable regardless of whether the application is made by the prosecution or the defence. 
Whilst the requirement of "real grounds" for fearing revelation of the witness' identity appears exacting, it has not raised the threshold at which a witness' fear justifies anonymity. The Court made no reference to any requirement of evidence of a threat to the witness, neither did it mandate an objective assessment of the likelihood of danger. Indeed, Evans LJ, consistent with the approach of Denison $\mathrm{J}$ in Brindle and Beldam LJ in ex $p$ Lenman, repeatedly implied that an assertion of fear would suffice. However, ECHR jurisprudence requires an assessment of the risk of threat before the use of anonymous witnesses can accord with the defendant's Convention rights. ${ }^{113}$ The Court of Appeal in Taylor undermined the first prerequisite as a safeguard for the defendant in two further respects: if the witness is not herself afraid, but others fear for her, that will justify the granting of anonymity to the witness; regardless of who is afraid, the consequences feared need not relate to the witness (for instance, they could presumably extend to her family).

There is an obvious problem in relation to the second factor identified in Taylor, that the witness' testimony is so important that it would be unfair to effectively deprive the prosecution of it by denying anonymity. As the Court itself recognised, the more important the evidence, the greater the prejudice to the defendant in permitting anonymity. Furthermore, judges are to consider whether the credibility of the witness is (or is likely to be) in issue or whether the question for the jury is simply one of the reliability and accuracy of the witness, in which case anonymity will more readily be granted. This fails to address the reality that notwithstanding its pre-trial disclosure obligations the prosecution alone is in a position to know whether the witness' credibility is questionable. There is little comfort for the defence in the third factor outlined in Taylor: whilst the court must be satisfied that the prosecution has thoroughly investigated the witness' credibility, the outcome of that inquiry must be disclosed to the defence "so far as is consistent with the anonymity sought."

With regard to the penultimate Taylor consideration, that granting anonymity would cause no undue prejudice to the defendant, the Court failed to acknowledge the nature and extent of the ensuing disadvantage. "'Undue' is a necessary qualification because some prejudice is inevitable if the order in question is made, even if that prejudice is only the qualification placed on the right to confront the witness as one of the defendant's accusers." 114 The actual prejudice engendered is the undermining of the presumption of innocence (because the defendant is insidiously identified as "dangerous" and, perhaps, "guilty") and of the requirement of full proof (because a prejudiced jury might be seduced into convicting where the evidence has not eliminated all reasonable doubts). Yet in the Court of Appeal's view this does not amount to "undue" prejudice. Indeed, it is a feature of the cases involving anonymous witnesses that the risk of prejudice to the accused is regarded as marginal ("theoretical", even, in ex $p$ Lenman) whilst the witness' fear is referred to in concrete terms.

The final matter to which a judge must have regard when adjudicating an application for witness anonymity is also unsatisfactory. The fundamental

113 Van Mechelen $\mathrm{v}$ The Netherlands, op cit $\mathrm{n} 83$.

114 Op cit $\mathrm{n}$ 106, transcript; emphasis added. 
difficulty with balancing the need for witness protection against the (appearance of) unfairness to the accused is the way in which the need for protection is assessed, which remains problematic in light of the guidance from Taylor taken as a whole. Furthermore, the Court of Appeal noted that the balancing of protection against unfairness includes the extent of protection which might be afforded to witnesses but provided no guidance as to the appropriate levels of protection in particular circumstances.

\section{(b) ECHR jurisprudence}

The Taylor guidance was approved by the Government's interdepartmental working group on vulnerable and intimidated witnesses. ${ }^{115}$ However, current United Kingdom law does not satisfy the requirements of ECHR jurisprudence and might not, therefore, survive a challenge under the Human Rights Act 1998.

\section{(i) Article 6 principles}

Article 6 of the ECHR has been developed by the European Court of Human Rights to provide both general procedural principles and specific rules relating to the use of anonymous witnesses. At a general level, Article 6 requires all evidence to be adduced at a public hearing, with a view to

adversarial argument. ${ }^{116}$ There are exceptions to this principle, ${ }^{117}$ but in any event defence rights must not be infringed. ${ }^{118}$ Any measures restricting defence rights must be strictly necessary and the least restrictive procedure possible must be used. ${ }^{119}$ A further general principle is that the defendant must have a proper opportunity to challenge a prosecution witness. ${ }^{120}$ This opportunity will be severely restricted where the defence is confronted with an anonymous witness, as the Court recognised in Kostovski $\mathrm{v}$ The Netherlands (1989):

"If the defence is unaware of the identity of the person it seeks to question, it may be deprived of the very particulars enabling it to demonstrate that he or she is prejudiced, hostile or unreliable. Testimony or other declarations inculpating an accused may well be designedly untruthful or simply erroneous and the defence will scarcely be able to bring this to light if it lacks the information permitting it to test the author's

\footnotetext{
115 Op cit $\mathrm{n} 3$.

116 Barbera, Messegue and Jabardo v Spain, 1988, Series A no. 146; Kostovski v The Netherlands op cit $\mathrm{n} 97$.

117 For instance, Article 6(1) permits the exclusion of the press or public from all or part of the trial "in the interest of morals, public order or national security. . . where the interests of juveniles or the protection of the private life of the parties so require, or to the extent strictly necessary. . . in special circumstances where publicity would prejudice the interests of justice."

118 Van Mechelen $\mathrm{v}$ The Netherlands, op cit $\mathrm{n} 83$.

119 Ibid.

120 Unterpertinger v Austria (1986) 13 EHRR 175; Kostovski v The Netherlands op cit $\mathrm{n}$ 97; Windisch case, judgment of 27 September 1990, Series A no. 186; Ludi v Switzerland op cit $\mathrm{n} 5$; Doorson $\mathrm{v}$ The Netherlands op cit $\mathrm{n} 5$; Van Mechelen $\mathrm{v}$ The Netherlands op cit $\mathrm{n} 83$.
} 
reliability or cast doubt on his credibility. The dangers inherent in such a situation are obvious." 121

ECHR jurisprudence has been influenced by the fact that the cases examined have involved anonymous witnesses who testified neither at the trial nor at the appeal stages in the national courts. ${ }^{122}$ Whilst the Strasbourg judicial authorities expressed strong concern about the use of anonymous witnesses in Kostovski v The Netherlands (1989), ${ }^{123}$ Windisch v Austria (1990) ${ }^{124}$ and Ludi v Switzerland (1992), ${ }^{125}$ what appears to have been decisive in these adverse judgments was the denial of the accused's right of confrontation. This interpretation is supported by two failed challenges to the use of anonymous witnesses: Baegen v The Netherlands (1994) ${ }^{126}$ and Doorson v The Netherlands (1996). ${ }^{127}$ In Baegen, although an anonymous victim of rape did not testify, the defence had been able to challenge her credibility at the appeal stage (the accused's counsel having discovered her identity). ${ }^{128}$ In Doorson, although the anonymous witnesses did not testify in open court, the defence lawyer was permitted to question them (albeit in the absence of the accused) at appellate stage in a hearing before the investigating judge. Nevertheless, although the dominant theme of the jurisprudence is the absence of witnesses rather than their anonymity, it has been established that affording the defence the opportunity to question anonymous witnesses will not, of itself, satisfy the requirements of Article 6 of the Convention.

Turning to more specific principles, challenges to the use of anonymous witnesses have required the Commission and the Court to consider the scope of the accused's right in Article 6(3)(d) "to examine or have examined witnesses against him." In Kostovski, material prosecution evidence was supplied by two informants, neither of whom testified at trial, though their statements were admitted as evidence. One of the informants was interviewed, in the absence of the defendant and his lawyer, by the examining magistrate who did not know the informant's identity. The other informant was interviewed only by the police. The defence was subsequently invited to submit written questions to the first informant (who, on the basis of anonymity, responded to only two of the fourteen questions) but had no opportunity to question the second. At trial, no questions about the informants' reliability and sources were permitted where the answers might

121 Op cit $\mathrm{n} 97$, para 42.

122 If the prosecution uses a statement given by a person who does not attend the trial, that person is considered a "witness" for the purposes of Article 6: Windisch case op cit $\mathrm{n} 120$; Ludi $\mathrm{v}$ Switzerland op cit $\mathrm{n} 5$; Kostovski $\mathrm{v}$ The Netherlands op cit $\mathrm{n} 97$.

123 Op cit $\mathrm{n} 97$.

124 Op cit $\mathrm{n} 120$.

125 Op cit $\mathrm{n} 5$.

126 Application 16696/90; Report of the Commission adopted on 20 October 1994.

127 Op cit $\mathrm{n} 5$.

128 The Commission was also influenced by the defence's failure to take opportunities to submit written questions to the anonymous witnesses, the accused's refusal to provide police with samples of blood and saliva, the right to respect for privacy of victims of sexual offences and the fact that the conviction did not rest solely on the statements of the anonymous witnesses (though their statements were arguably decisive). The case was not considered by the European Court of Human Rights. 
have revealed their identity. The European Court of Human Rights observed that although the defence had been able to question two examining magistrates, a police officer and, indirectly, one of the informants, the scope and nature of the permissible questioning was significantly limited by the decision to preserve anonymity. Furthermore, the trial and appellate courts had no opportunity to assess the informants' reliability independently through observation of their demeanour. In finding a violation of Article 6, the Court stated that witness intimidation, though a serious concern, could not justify the denial of a fair administration of justice. The Court held that where anonymous witnesses are used, the disadvantages to the defence must be counterbalanced by the procedures adopted by national judicial authorities. Moreover, the Court established that whilst reliance at investigative stage on anonymous informants is not necessarily incompatible with the Convention, a conviction can never be founded solely or to a decisive extent on the statements of anonymous witnesses. ${ }^{129}$ The failure of national courts to observe these principles led to adverse judgements in Windisch v Austria (1990) ${ }^{130}$ and Ludi v Switzerland (1992), ${ }^{131}$ in which the defence had been denied the right of confrontation with absent, anonymous witnesses whose identity was not disclosed to the trial and appellate courts.

\section{(ii) Specific procedural requirements}

A detailed examination of the procedure challenged in the leading cases on anonymous witnesses, Doorson v The Netherlands ${ }^{132}$ and Van Mechelen v The Netherlands, ${ }^{133}$ demonstrates the inadequacy of the Taylor guidance provided by the United Kingdom Court of Appeal. ${ }^{134}$ In Doorson, the defendant was convicted of drug dealing; the evidence of two named witnesses ("R" and "N") and two anonymous witnesses ("Y15" and "Y16") was decisive. All the witnesses were drug addicts who had identified the accused from police photographs; at no stage in the proceedings was there a direct confrontation between the defendant and R, Y15 and Y16. Prior to the trial the investigating magistrate, contrary to an undertaking, interviewed the anonymous witnesses in the absence of Doorson's lawyer. The Regional Court refused to call those witnesses but received their statements as evidence. The named witness $\mathrm{R}$ did not comply with the Court's summons;

129 Confirmed in Doorson $\mathrm{v}$ The Netherlands op cit $\mathrm{n}$ 5; Van Mechelen $\mathrm{v}$ The Netherlands op cit $\mathrm{n} 83$.

130 Op cit $\mathrm{n} 120$.

131 Op cit $\mathrm{n} 5$

132 (1996) 22 EHRR 330.

133 (1998) 25 EHRR 657.

134 Following the European Court's decision in Kostovski, the Netherlands Supreme Court provided procedural guidance on the use of anonymous witnesses ((1990) NJ, No 692). The guidance influenced the appellate stages of the Doorson and Van Mechelen cases. On many points, the Supreme Court's guidance was less rigorous than that established in Taylor, but it did require judicial assessment of the witness' reliability and of his/her reasons for desiring anonymity. The Supreme Court also adopted the European Court's ruling that a conviction should not be decisively based on the statements of anonymous witnesses and further required the trial court to explicitly state that the statements had been used with caution and circumspection. Subsequently, the Protection of Witnesses Act 1993 amended the Code of Criminal Procedure (section 226a) to regulate the use of anonymous witnesses. 
$\mathrm{N}$ retracted his police statement, explaining that he had lied in order to secure the return of his confiscated drugs. On appeal against conviction, the Amsterdam Court of Appeal requested that the investigating judge reexamine Y15 and Y16 in order to verify the need for anonymity and to provide Doorson's lawyer with the opportunity to question the witnesses. The Court of Appeal accepted the judge's report that the anonymous witnesses (whose identities were known to her) had firm grounds for anonymity: Y15 had been threatened by drug dealers in the past and Y16 had suffered violent reprisal; both stated that they were afraid of the defendant. Nine months later at the request of the Court of Appeal, the investigating judge, without further examination of the anonymous witnesses, provided a limited endorsement of their reliability. In relation to the named witnesses, $\mathrm{R}$ absconded before he could be heard and $\mathrm{N}$ repeated the retraction of his police statement. The Court heard a further named witness, a police officer who testified that although he had never known the defendant to be violent or to issue threats, such future behaviour could not be discounted as drug dealers often exacted reprisals against those who incriminated them.

In a majority decision, the Commission found that there had been no violation of Article 6 because the investigating judge knew the identity of the anonymous witnesses (who had a well-founded desire to remain unidentified) and because the defence lawyer had been able to question them at the hearing before the judge. The European Court reached the same decision, noting that although the anonymity of Y15 and Y16 had "presented the defence with difficulties which criminal proceedings should not normally involve," 135 the procedures employed by the national courts afforded the defence sufficient compensation. The Court found additionally that although fear of reprisal was a relevant reason for witness anonymity, it was not necessarily a sufficient one. In the present case, anonymity was justified on the basis of police knowledge that drug dealers were frequently violent to those who had testified against them and by reason of the fears expressed by the unidentified witnesses. The Court was satisfied that the Amsterdam Court of Appeal had treated the anonymous statements with extreme care and that it had not based its conviction to a decisive extent on that evidence. Both these observations may, however, be criticised. In Kostovski, the European Court declared that a cautious evaluation of statements by anonymous witnesses "can scarcely be regarded as a proper substitute for direct observation."136 In relation to the basis of the conviction in Doorson, the Amsterdam Court stated that its decision was founded mainly on the evidence of the four witnesses; yet $\mathrm{R}$ was heard only by the police and $\mathrm{N}$ consistently testified that he had lied in his police statement. In these circumstances, it seems inescapable that the statements of the anonymous witnesses were decisive.

In Van Mechelen $\mathrm{v}$ The Netherlands, the defendants were convicted of attempted homicide and robbery with the threat of violence. The only identification evidence consisted of statements by eleven anonymous police officers. The officers were not interviewed by an investigating judge prior to the trial and they did not testify before the Regional Court, which remained

135 (1996) 22 EHRR 330, para 72 at 359.

136 Kostovski v The Netherlands (1989) 12 EHRR 434, para 43. 
unaware of their identity. The Court of Appeal referred the case back to the investigating judge to clarify the basis for anonymity and to examine the witnesses in the presence of the defence. These hearings took place in two separate rooms connected by a sound link. The investigating judge, each witness and the registrar were present in one room, while the defendants, their lawyers and the Advocate General were in the other. Most of the police officers explained that they wished to remain anonymous to protect their families and friends, with some giving the additional reason of preserving their operational value as undercover officers. The defence was given the opportunity to question the witnesses at length. When the Court of Appeal hearing resumed (at which the defendants were convicted), the reasons for maintaining anonymity were explained:

"Of the arguments for continuing the anonymity of the witnesses, the Court of Appeal considers particularly persuasive the personal safety of these witnesses and their families, and it makes no difference that these witnesses have not yet been threatened. . . [T]he present case concerns extremely serious crimes, the [attempted murder] having been committed so as to evade recognition and arrest by the police, the perpetrators having been prepared to sacrifice a number of human lives. In these circumstances, the risk run by the witnesses identified only by a number and their families if their anonymity is lifted or insufficiently guaranteed is decisive. In so far as anonymous witnesses have refused to answer questions this was done in order not to disclose methods of investigation or to maintain the anonymity of other investigating officers involved in the case." 137

Nevertheless, the European Court found that the use of anonymous witnesses was incompatible with Article 6. The Court distinguished the case from that of Doorson: in the latter the foundation for anonymity was more clearly established, the anonymous witnesses were heard in the presence of defence counsel and there was identification evidence from named witnesses. The tenor of the Van Mechelen judgment, however, conveys the impression that a similarly constituted Court would have found a violation in Doorson. Indeed, in light of the existing ECHR jurisprudence and of the arguably greater restrictions on the defence, Doorson was a surprising decision.

The Van Mechelen judgment refined and supplemented the existing Convention jurisprudence on anonymous witnesses in four main ways. First, although it had been established that it is incumbent on national courts to consider less restrictive forms of witness protection, the Court made it clear that this obligation will not be discharged simply by declaration. A related requirement of Article 6 is that prior to granting anonymity, courts must conduct an informed assessment of the risk of reprisals against witnesses seeking such protection. Specifically, the court should assess the ability of the defendant to exact reprisals or to secure others to do so on his behalf. The European Court requires national courts to demonstrate that this inquiry has been conducted. The second main development in Van Mechelen is that by virtue of their connection with the State, police officers should be given

137 Cited by the European Court of Human Rights (1998) 25 EHRR 657, para 26. 
anonymity only in exceptional circumstances. Furthermore, the desire to preserve the operational usefulness of undercover officers will not, of itself, justify anonymity: there must also be an established threat to the safety of the officers or their families. Thirdly, the defence must be able to question anonymous witnesses in their presence. Finally, the Court established for the first time that the defence must be able to assess the reliability of anonymous witnesses through observation of their demeanour. This is a significant development: previous cases had emphasised the importance of the court being able to observe demeanour. The current position is that a judicial assessment of the witnesses' reliability and credibility will not suffice. Even if a judge, having ascertained the witnesses' identity, directly questions them about their reasons for seeking anonymity and provides a detailed account of his findings as to their reliability and credibility, this will not represent sufficient compensation for the disadvantages caused to the defence. The Court regarded the entitlement of the defence to assess reliability as distinct from the right to question witnesses in their presence. It follows that the defence must be permitted to see the anonymous witness; the fact that the defence in Van Mechelen was able to hear the witnesses was not, in the Court's view, an adequate indicator of reliability. This decision implicitly acknowledges the importance of visual clues to the development of cross-examination strategy. Furthermore, it will allow the defence to challenge the assessment of a witness' reliability presented by the prosecution (and the judge).

\section{(iii) Compatibility of domestic law with ECHR jurisprudence}

Domestic law regulating the use of anonymous witnesses satisfies neither the general tenets of Article 6 of the Convention, nor the specific principles developed by the European Court of Human Rights from the Article 6 (3) right of confrontation. According to ECHR jurisprudence, national courts must conduct a thorough and objective examination of the existence and level of any risk of harm to a prosecution witness before granting anonymity. Furthermore, anonymity should only be resorted to if other forms of witness protection would not suffice. The Court of Appeal in Taylor, ${ }^{138}$ however, indicated that a mere assertion of fear, without any evidence of a threat to the witness, would justify concealment of identity. Although the Court noted that judges could consider protective measures short of anonymity, it did not direct them to do so. There has been no appreciation in domestic courts of the particular concern surrounding the granting of anonymity to law enforcement officers.

It is a well-established Convention principle that where anonymous witnesses are used, the consequent limitations on the defence must be counterbalanced by procedural measures. These measures must provide the defence with the opportunity to question the witnesses in their presence and to assess reliability through direct observation of demeanour. United Kingdom law, however, permits the adduction of witness statements where a witness does not attend the trial. ${ }^{139}$ Indeed, the House of Lords has endorsed the admission at coroners' inquests of statements by anonymous soldiers

\footnotetext{
138 Op cit $\mathrm{n} 106$.

139 Criminal Justice Act 1988, s 23.
} 
exempted from attending the hearings even though they were suspected of causing the deaths. ${ }^{140}$ In relation to observation of demeanour, United Kingdom jurisprudence accords with Article 6 insofar as anonymous witnesses have not been screened from defence lawyers during testimony. Nevertheless, the jury's ability to assess credibility remains problematic by virtue of the prosecution's control of witness information, the enhanced status of anonymous witnesses and, in terms of physical indicators of veracity and accuracy, the use of screens and voice-distortion equipment.

The European Court of Human Rights has emphasised the importance of regarding anonymous statements with extreme caution. As Jane Liddy has observed, ${ }^{141}$ permitting unidentified police officers to refuse to answer questions on the basis that investigation methods or other officers would otherwise be revealed does not exhibit caution. Operational secrecy is a privilege routinely extended to law enforcement witnesses, but when combined with personal anonymity (as in the Jack case), ${ }^{142}$ the dangers in relying on the testimony of such witnesses are increased. Indeed, to base a conviction solely or to a decisive extent on anonymous statements contravenes Article 6. Yet the Court of Appeal in Taylor stated that the prospect of anonymity increases commensurately with the importance of the prosecution witness' testimony, raising the possibility of a direct contravention of the Convention.

\section{CONCLUSION}

There are two principal difficulties with the United Kingdom courts' approach to witness anonymity: the conception of anonymity as impacting chiefly on open justice (itself viewed at an abstract level, rather than taking cognisance of the accused's procedural, legal rights) and the notion of "balance" in the criminal justice system. Of course, fairness in criminal procedure does not reside exclusively in the domain of defendant rights: it is trite to note that in order to sustain the public support vital to the legitimacy of the criminal justice system, the courts must give expression to the public interest in the successful prosecution of offenders. But the traditional view of criminal justice, that it involves a balancing act between the conflicting objectives of the effective implementation of the criminal law and the protection of the defendant, leads inexorably to the conclusion that safeguards instituted to protect those accused of criminal conduct represent a hindrance to the aim of crime suppression. ${ }^{143}$ Yet due process is not inconsistent with the notion of crime suppression: as a normative model, it prescribes the procedure to be employed in the prosecution of offenders. Although the due process model is commonly seen to imply a reduction in the efficiency of the criminal process, this view is predicated on the notion

140 Devine v Attorney General for Northern Ireland, Breslin v Attorney General for Northern Ireland [1992] 1 All ER 609.

141 Van Mechelen and others v The Netherlands, Application Nos 21363/93; 21364/93; 21427/93; 22056/93, Report of the European Commission of Human Rights, 27 February 1996. The Commission concluded (20:8) that there was no violation of Article 6; Jane Liddy provided a dissenting opinion.

142 Op cit $\mathrm{n} 79$.

143 See further, J Jackson, "Getting Criminal Justice out of Balance" in J Morison and S Livingstone (eds), Law, Society and Change (1991), pp $114-133$. 
that fact-finding reliability is of secondary importance as a value. But public confidence is not secured simply by high rates of prosecution and conviction, as the reaction to publicised miscarriages of justice has shown; adherence to due process is essential to the very legitimacy of the criminal justice system. The choice need not be viewed as one of giving pre-eminence either to crime control values or to those reflecting due process. Different values can be, and to an extent are, accommodated in our criminal justice system. If witness anonymity is necessary in exceptional cases, this may be afforded provided the limitations consequent on the defence are to some extent compensated for and defence rights are not infringed.

The courts' current response to the problem of witness intimidation violates fundamental principles of criminal justice and contravenes international human rights law. There should be a rigorous judicial approach to claims for witness anonymity, coupled with the implementation of effective safeguards for the defence. Although the judiciary has thus far failed to appreciate the nature and extent of the encroachment of anonymity on defence rights, it is to be hoped that the Human Rights Act 1998 will encourage judicial activism in the safeguarding of the legal right to a fair trial. 